\title{
4 \\ Archaeological Investigations at Savidug, Sabtang Island
}

\section{Peter Bellwood and Eusebio Dizon}

This chapter is focused on the site complex near Savidug village, roughly half way down the eastern coast of Sabtang Island, facing across a sea passage to the southwestern coastline of Batan. The Sabtang site complex includes an impressive ijang of sheer volcanic rock, which we surveyed. A sand dune to the north, close to Savidug village itself, contained two distinct archaeological phases separated by about a millennium of non-settlement in the site. We also excavated another small late prehistoric shell midden at Pamayan, inland from Savidug village.

In 2002, brief visits for reconnaissance purposes by the Asian Fore-Arc Project were made to Sabtang and Ivuhos Islands (Bellwood et al. 2003). As a result, one week was spent on Sabtang in 2003, during which time a plane-table survey and test excavations were carried out at Savidug ijang, and the Pamayan shell midden at the back of Savidug village was test-excavated. The location of Savidug village is indicated on Fig. 4.1, half way down the eastern coast of Sabtang and facing the southern end of Batan, $5 \mathrm{~km}$ across the ocean passage to the northeast.

In 2006, test-excavation was undertaken at the Savidug Dune Site (Nadapis), which yielded a sequence extending back 3000 years incorporating two separate phases of human activity commencing with circle stamped pottery dated to $c .1000 \mathrm{BC}$ and very similar to that anaro on Itbayat and Sunget on Batan. In 2007, Savidug Dune Site was subjected to further excavation for 3 weeks, resulting in the recovery of several large burial jars, Taiwan nephrite, and a more thorough understanding of the nature of the whole site.

Sabtang Island is mainly volcanic, geologically older than Batan and no longer active. The interior rises up to a number of volcanic ridges and pinnacles reaching a maximum of $347 \mathrm{~m}$ above sea level (Fig. 4.2). The central portion of the east coast consists of a dissected high terrace, possibly a former uplifted coastline (although no geomorphological survey has been undertaken), broken by a number of narrow west-to-east stream beds that are dry for most of the year. Savidug village lies just to the north of a stream bed called Padudugan. On its southern side lies the Savidug Dune Site, with Savidug ijang occupying a volcanic agglomerate plug in the lower part of the next valley system to the south (Fig. 4.3). The ijang lies about $500 \mathrm{~m}$ inland and about $800 \mathrm{~m}$ southwest of the Dune Site, as indicated on Fig. 4.1. 
The central eastern coastline of Savidug, from south of the town of San Vicente to about 2 $\mathrm{km}$ south of Savidug, is flanked by sand dunes (Fig. 4.3) that rise behind the modern lagoon shoreline. This shallow lagoon is a valuable resource for marine products, 2-3 metres deep in places at high tide but mainly exposed sea grass, sand and rock at low tide. Both Pamayan and the Savidug Dune Site contained large quantities of exploited shellfish, particularly in late prehistoric layers when population pressure on resources was clearly very high.

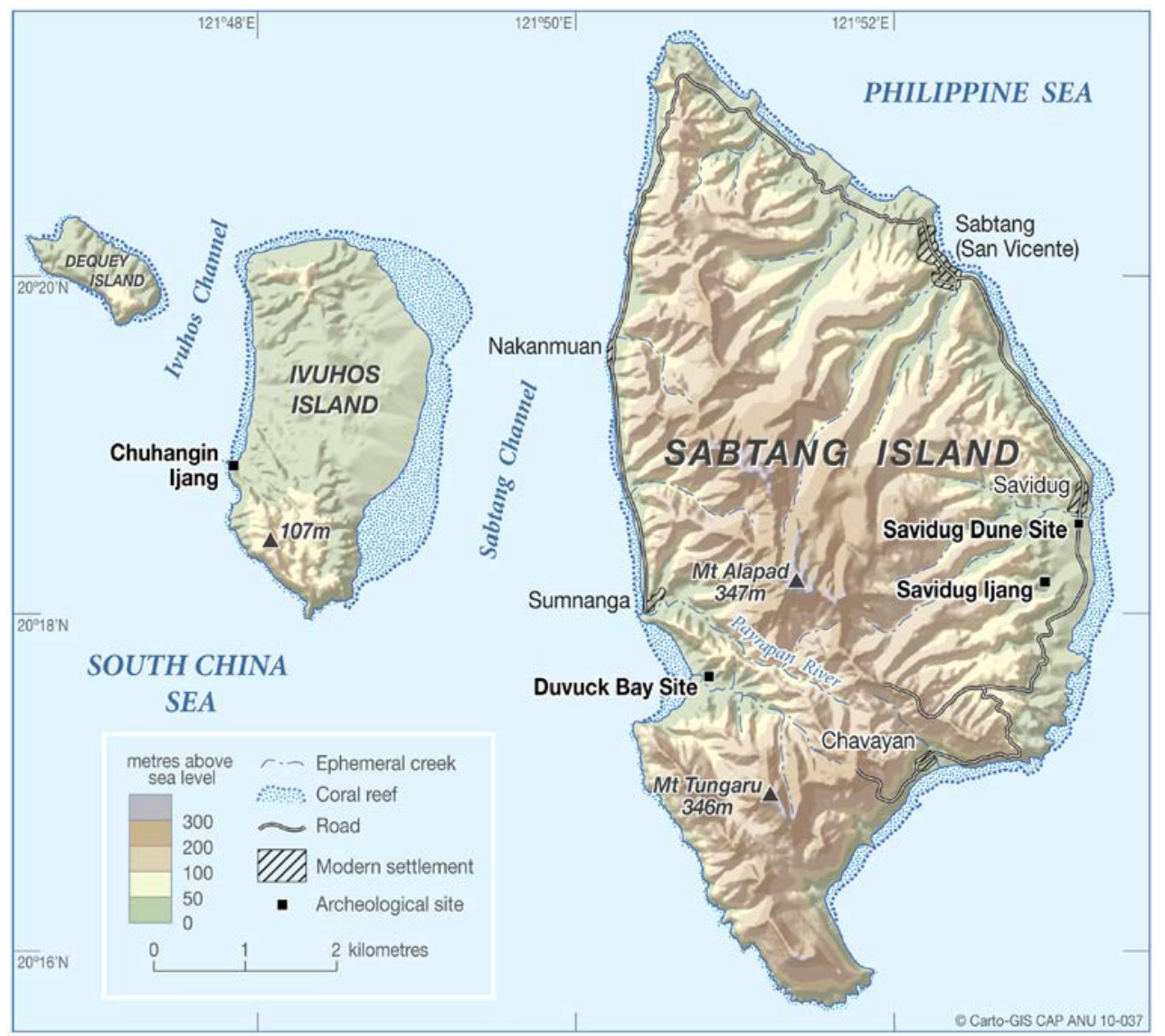

Figure 4.1. Sabtang, Ivuhos and Dequey Islands.

Source: Map preparation by ANU College of Asia and the Pacific, CartoGIS.



Figure 4.2. Sabtang Island, on approach from the south.

Source: Peter Bellwood. 


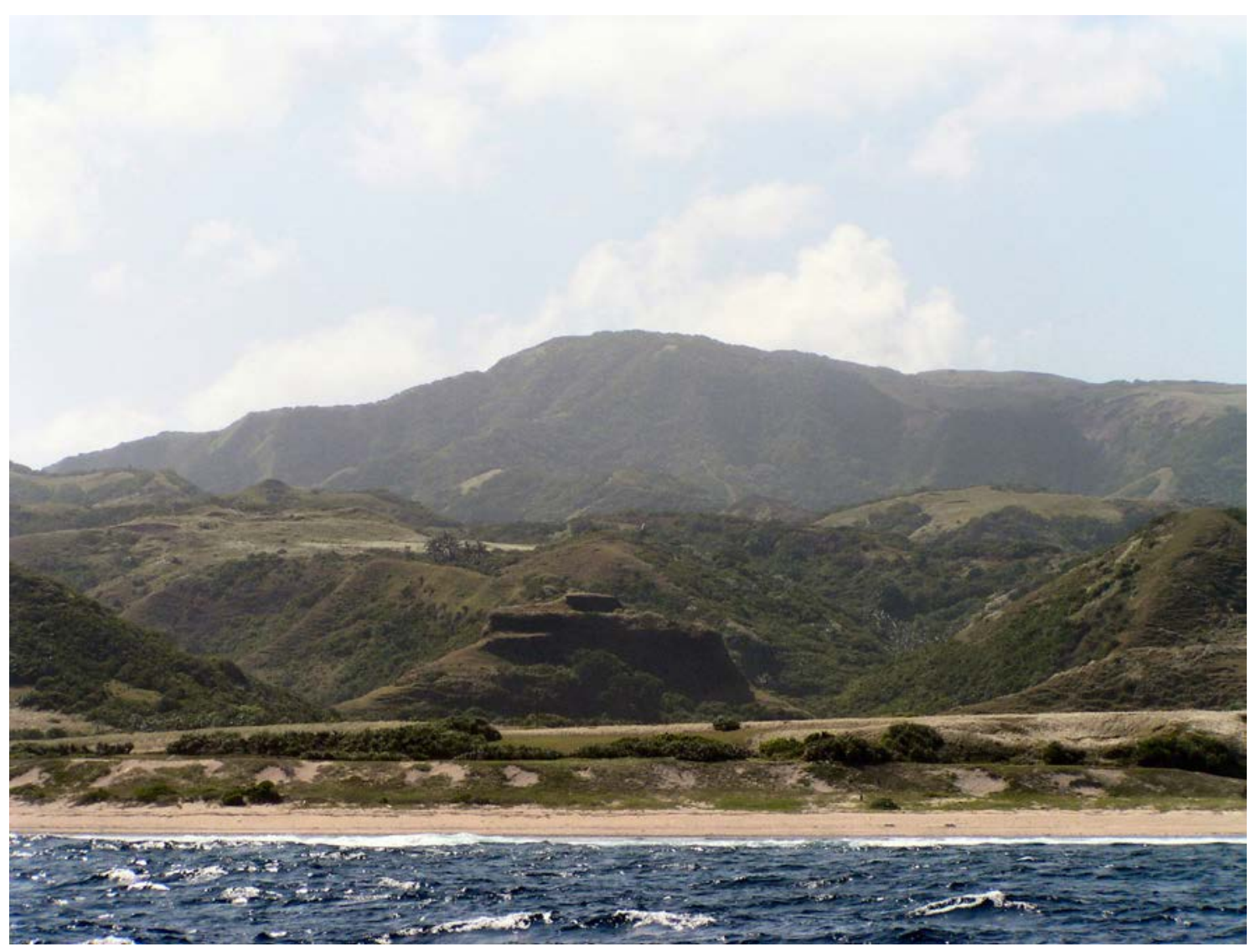

Figure 4.3. Savidug ijang, the drum-shaped feature in the middle foreground behind the beach and sand dune.

Source: Peter Bellwood.

\section{The Savidug sites}

\section{Savidug Ijang}

Savidug ijang lies about $1.2 \mathrm{~km}$ southwest of Savidug village and is the most impressive of all the Batanes ijang. Dampier probably saw it in 1687, although he gives no indication of visiting the site. A very useful survey of the central part of the ijang was made by a National Museum team in 1994 (Dizon and Santiago 1994: Fig. 14), to which the 2003 survey added the surrounding living and agricultural terraces shown in Fig. 4.4.

The central part of Savidug ijang consists of a volcanic plug of agglomerate that rises like a drum, almost sheer from the surrounding terrain, up to 40 metres high on its northern side (Fig. 4.5). The plug has a small triangular summit platform of natural origin, surrounded by a large and relatively flat area that runs out to the top of the surrounding cliff. This area is now overgrown by very tall grass and shrubs since goats and cattle are unable to scale the only access point, a steep climb up a 4 metre cliff on the inland side. A few stone walls, stone piles (for defensive throwing?), and four perforated columns of prismatic andesite are still visible on the summit. In 1994 this area was apparently clear of vegetation, and a number of rectilinear stone walled enclosures were sketched on the plan made at that time (Dizon and Santiago 1994: Fig. 14). Two of the four perforated columns stand today about $4.5 \mathrm{~m}$ apart as though at either end of a house (the other two are recumbent), but we suspect that re-erection of these columns could have occurred in recent times (Fig. 4.6). The summit also has a surface scatter of sherds, all of 
recent and unslipped types. When occupied, this whole summit area would have been accessible either by ladder, as described for other ijang by Dampier, or by climbing up the rear access route marked in Fig. 4.4.

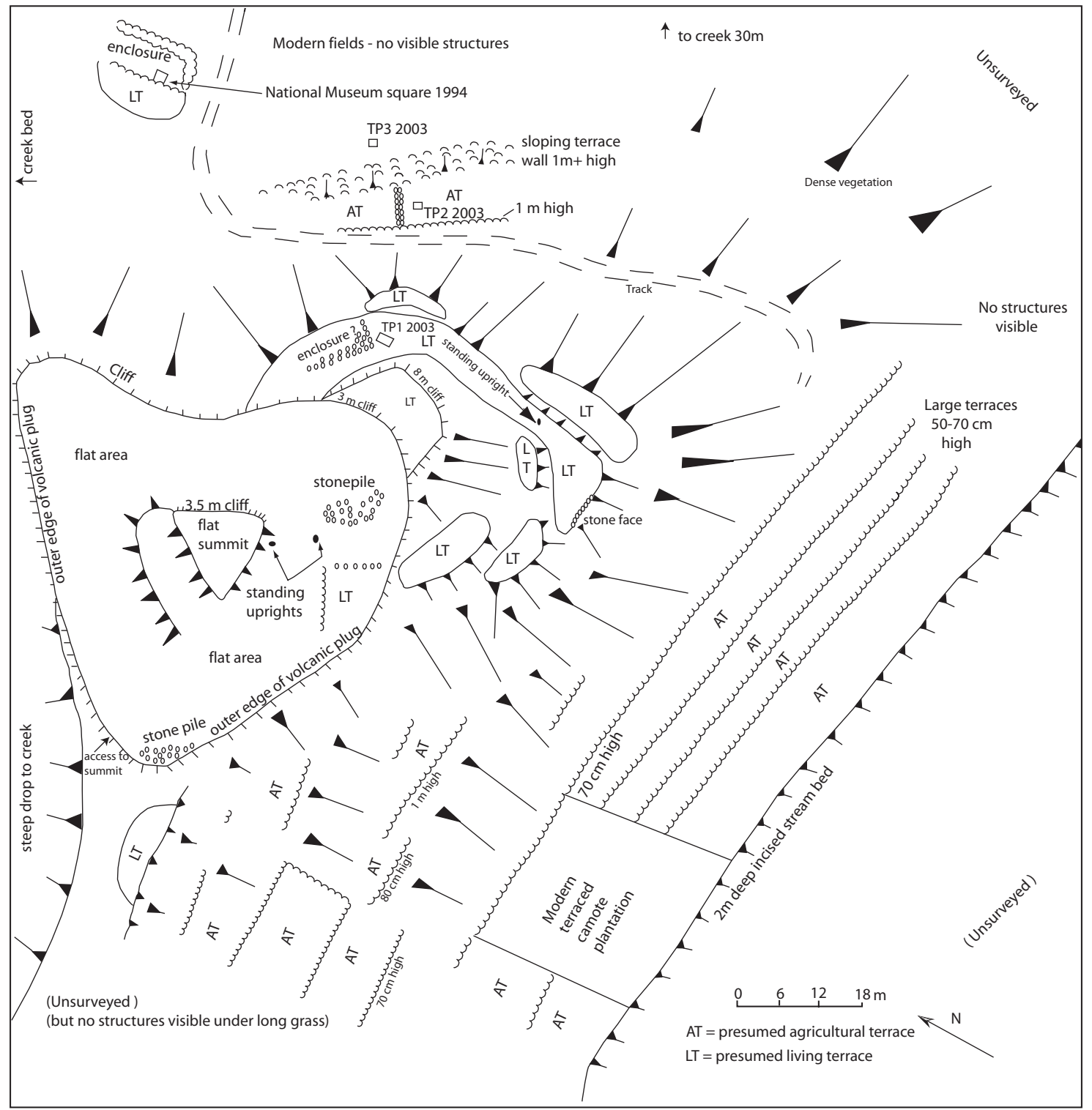

Figure 4.4. Plan of Savidug ijang, surveyed in 2003, showing the extent of visible terracing round the main volcanic tower.

Source: Map preparation by ANU College of Asia and the Pacific, CartoGIS.

Below the summit area, on the eastern (seaward) side of the tower, lie seven terraces. On the largest there is still one standing upright (marked on Figs 4.4, 4.5). Our excavation of a 2 by $1 \mathrm{~m}$ test trench in 2003 (TP1), at the other end of this terrace, produced about $20 \mathrm{~cm}$ of archaeological deposit over decomposed volcanic material. Three postholes about $20 \mathrm{~cm}$ across by $30 \mathrm{~cm}$ deep had been dug into the soft substrate, and they were clearly large enough to have supported prismatic stone or perhaps timber house columns (Fig. 4.7). One of these holes contained a glass bead, and all pottery found was of relatively recent date. These terraces appear to be mainly of natural origin, although some artificial levelling might have occurred; they are labelled "living terraces" (LT) on Fig. 4.4. None are stone faced, except in one small area, and all can be easily approached by walking up from the track below. 


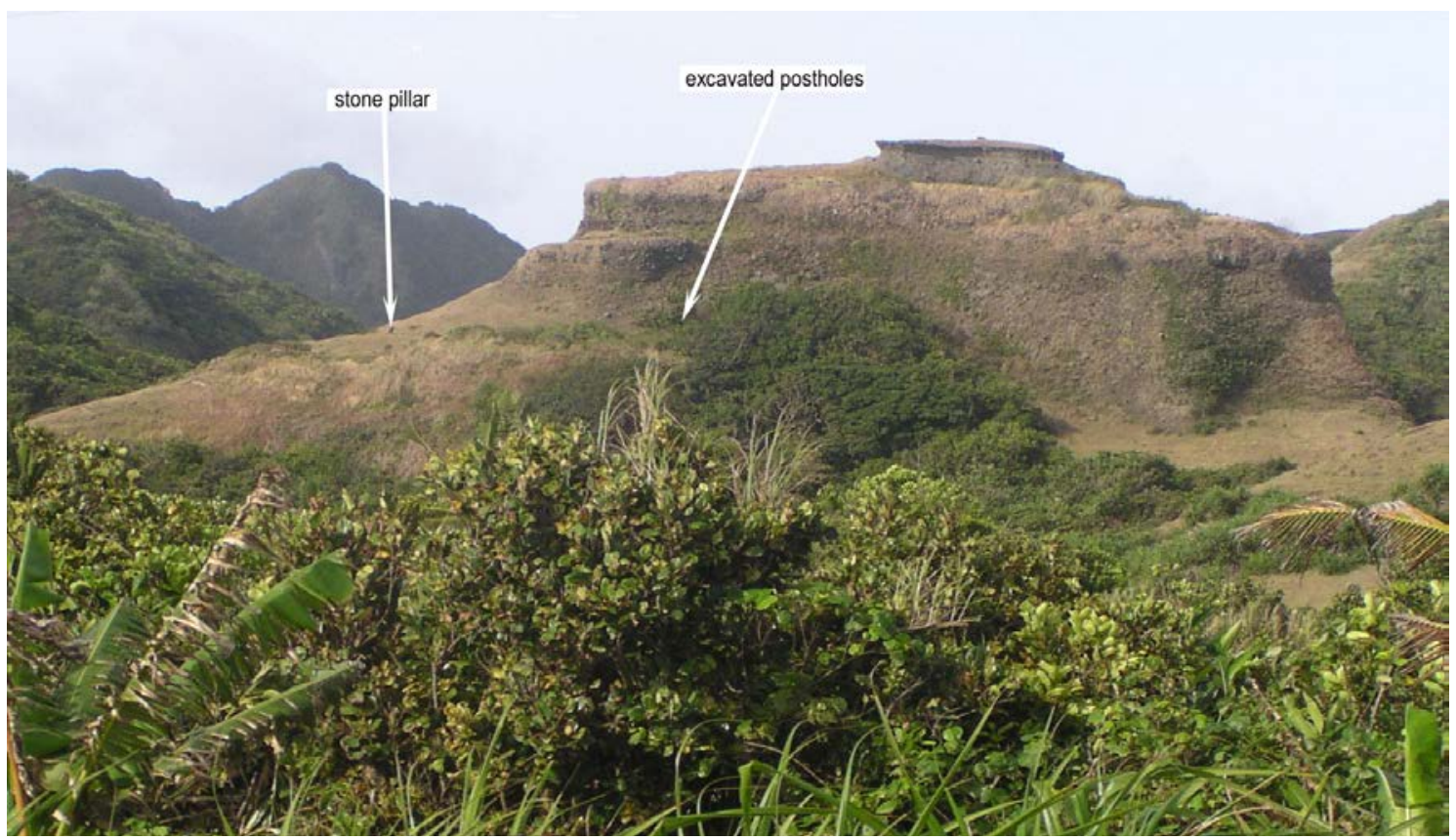

Figure 4.5. Savidug ijang from the ocean side. The arrows point to the location of the excavated postholes and to a surviving stone pillar that still stands on a terrace.

Source: Peter Bellwood.

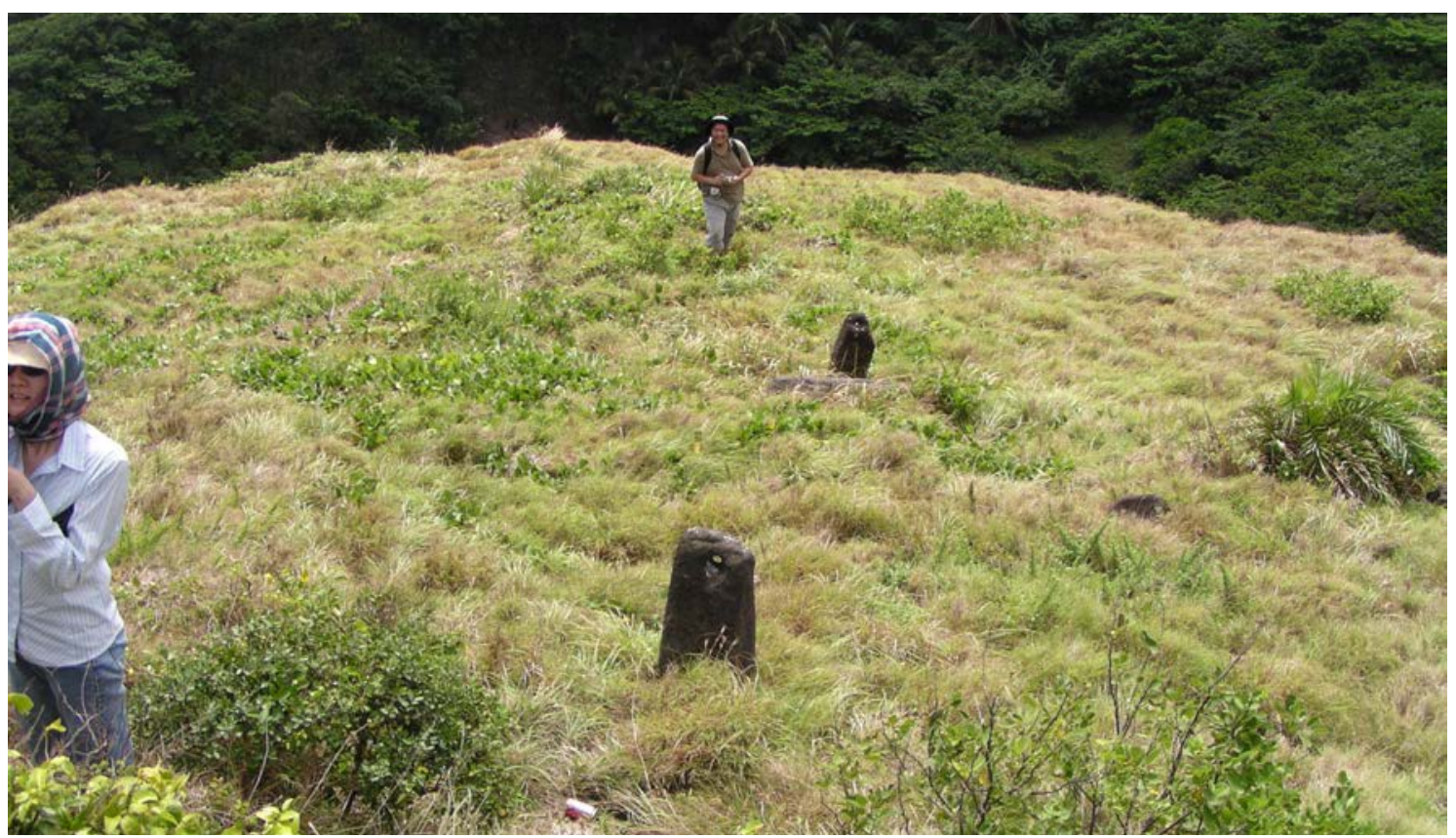

Figure 4.6. Two perforated stone uprights still standing on the top of Savidug ijang (Daud Tanudirjo at rear, Hsiao-chun Hung at left).

Source: Peter Bellwood. 


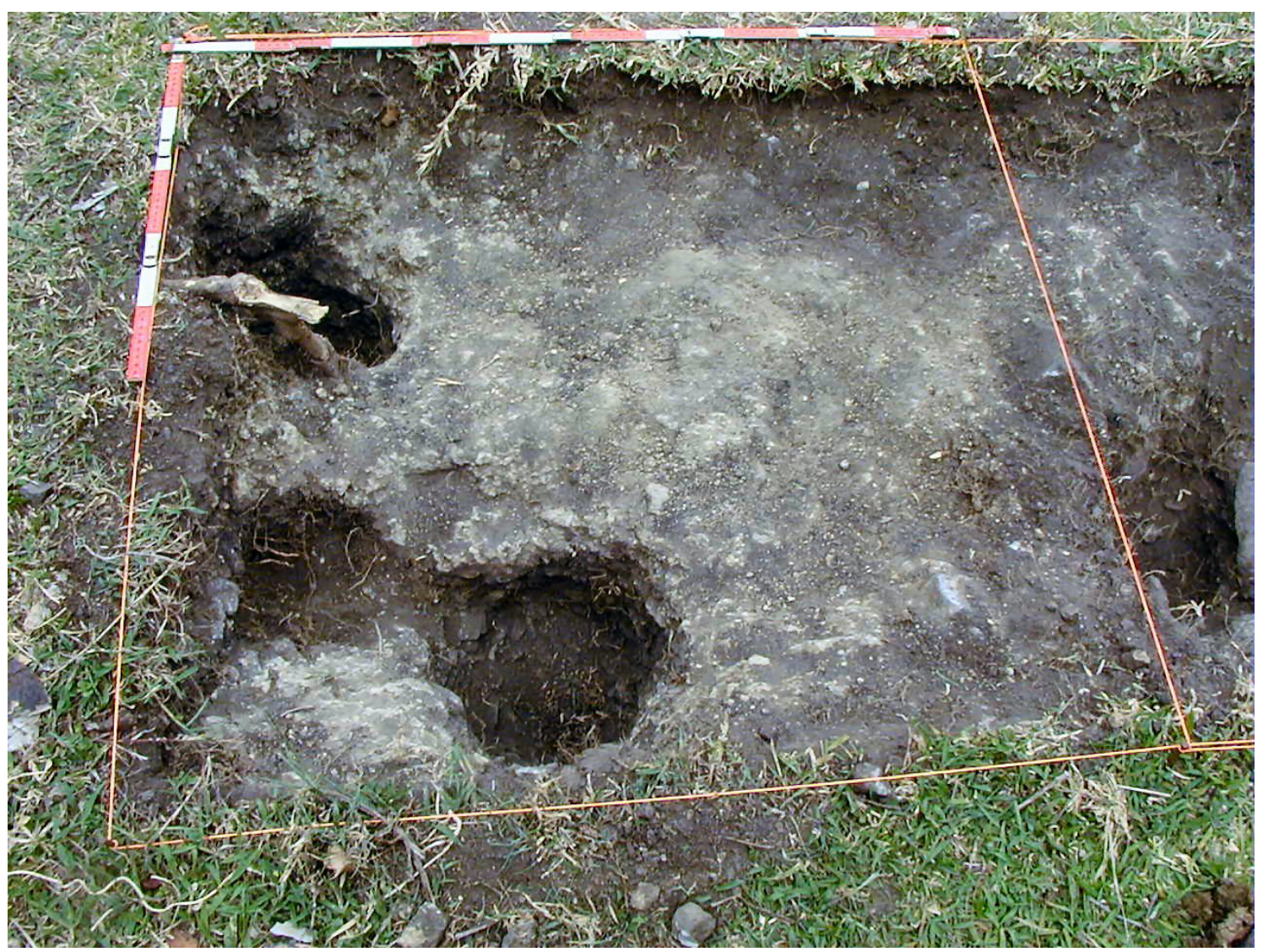

Figure 4.7. Savidug ijang: terrace postholes excavated in TP1, 2003. Scale is in $10 \mathrm{~cm}$ units.

Source: Peter Bellwood.

To the west and south of the ijang there are many terraces of a different type, built of soil rather than levelled into rock and all faced with dry stone walls up to one metre (up to 6 stone courses) high. Most are under pasture today, and the terrace faces have been damaged by cattle except where protected by dense vegetation. Their surfaces now slope slightly away from the ijang, towards the stream bed below the site, and one area is still in use with modern terrace walls for cultivation of camote (sweet potato). They are interpreted as agricultural rather than living terraces, and if Savidug was still in use in 1687 they could by then have been growing camote, as well as traditional crops such as yams, bananas and sugarcane.

Two small excavations (TP 2 and 3) were made in lower terraces on the seaward side of the ijang in 2003, complementary to that dug by Dizon in 1994 in an enclosure to the northeast (Dizon and Santiago 1994). All contained redeposited materials fallen down from the ijang above, in all cases of recent date and including Song and Yuan Chinese ceramics. TP 3 was dug to a depth of $110 \mathrm{~cm}$, from which level a charcoal date of $760 \pm 190$ uncal. BP (ANU 12070) was processed. Neither the 2003 nor the 1994 squares reached bedrock owing to time constraints, but surface finds of red-slipped pottery identical to those dated between 3000 and 2000 BP from the lower cultural layer in Savidug Dune Site (below) were found on the seaward slope of the ijang in 2003, above the track close to TP 2, so occupation of this phase on or around the ijang is confirmed. 


\section{Pamayan, Savidug village}

The Pamayan shell midden lies at the back of Savidug village, exposed by a road cutting along the base of a limestone hill that is today under forest. Our discovery of the site was accidental, when walking through the village one day in 2003. Red-slipped pottery, a broken chert pebble and a circumferentially worked operculum of a large Turbo indicated the existence of an interesting site that we thought then could be quite early in chronological terms. This turned out to be a little optimistic.

Two small excavation sections of 60 by $80 \mathrm{~cm}$ were excavated $16 \mathrm{~m}$ apart back into the section exposed in the road cutting, exposing shell midden to a maximum depth of $105 \mathrm{~cm}$ beneath the topsoil (Fig. 4.8). Sherds occurred fairly evenly and densely through this depth, together with a single shell disc bead and prolific food shells consisting almost entirely of broken small cowries. The recency of the Pamayan midden was rendered obvious by the occurrence of imported Chinese sherds down to $95 \mathrm{~cm}$ depth, and by the fact that bone preservation is very good, whereas at 3000-year-old Sunget on Batan, with an identical neutral $\mathrm{pH}$ in soil formed over limestone, it is very poor. A C14 date from the base of the cultural layer, on charcoal, is only $418 \pm 41$ uncal. BP (WK 13091).

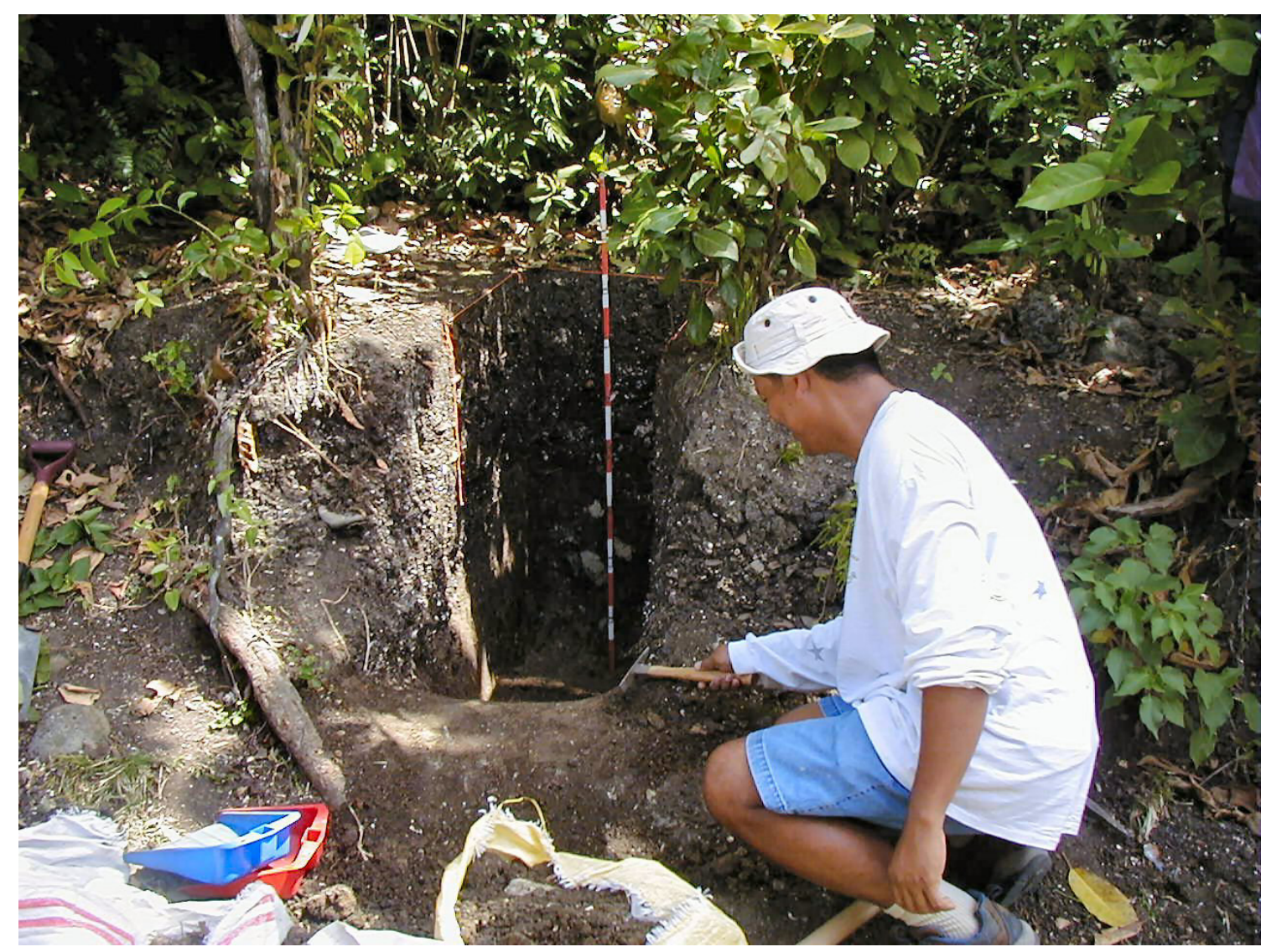

Figure 4.8. Pamayan cutting B, showing about $1 \mathrm{~m}$ of midden in the section. Tony Peñalosa in foreground.

Source: Peter Bellwood.

In 2007, we excavated a long cultural sequence from the Savidug Dune Site, as described below, with the uppermost phase, associated with Chinese imported ceramics, being similar in material culture to Pamayan. Both of these occupation deposits can be placed at the end of the Sabtang 
sequence, albeit with well-made red-slipped but otherwise undecorated pottery in the case of Pamayan. Both deposits also revealed intensive breakage of small cowrie shells, a presumed sign of late prehistoric population stress on diminishing resources (Table 4.1).

\section{Savidug Dune Site (Nadapis)}

South of Savidug village, just across Padudugan Creek, begins a large sand dune about 120-150 $\mathrm{m}$ wide that runs south for about $800 \mathrm{~m}$ to the next valley, the one that contains Savidug ijang (Fig. 4.9). The area has the local name of Nadapis. The archaeological site lies at the northern end of the dune, close to where it meets an $8 \mathrm{~m}$ bluff formed of volcanic deposits and raised coral, immediately west of the road (Fig. 4.10). Two large concrete water tanks stand on top of this bluff. The road to Chavayan runs longitudinally along the top of the dune, and where it rises up from Padudugan Creek there is a cutting up to $2 \mathrm{~m}$ deep, formed as a hollow way (visible in Fig. 4.10) by the long-term passage of foot, sledge, cart and sometimes vehicle traffic. In both sides of this road cutting, within the area of the grid shown on the site plan in Fig. 4.11, we first noted in 2003 a total of nine projecting burial jars exposed by erosion. On this first visit little understanding was acquired of the stratigraphy of the site, but the nine visible jars were located about 4 to $6 \mathrm{~m}$ apart within the area of the subsequent 2007 survey grid, with five on the inland side of the road and four on the seaward side. The latter were located close to a large number of modern lime pits dug into the sand dune to fire lime mortar for Savidug village (visible in Fig. 4.9).

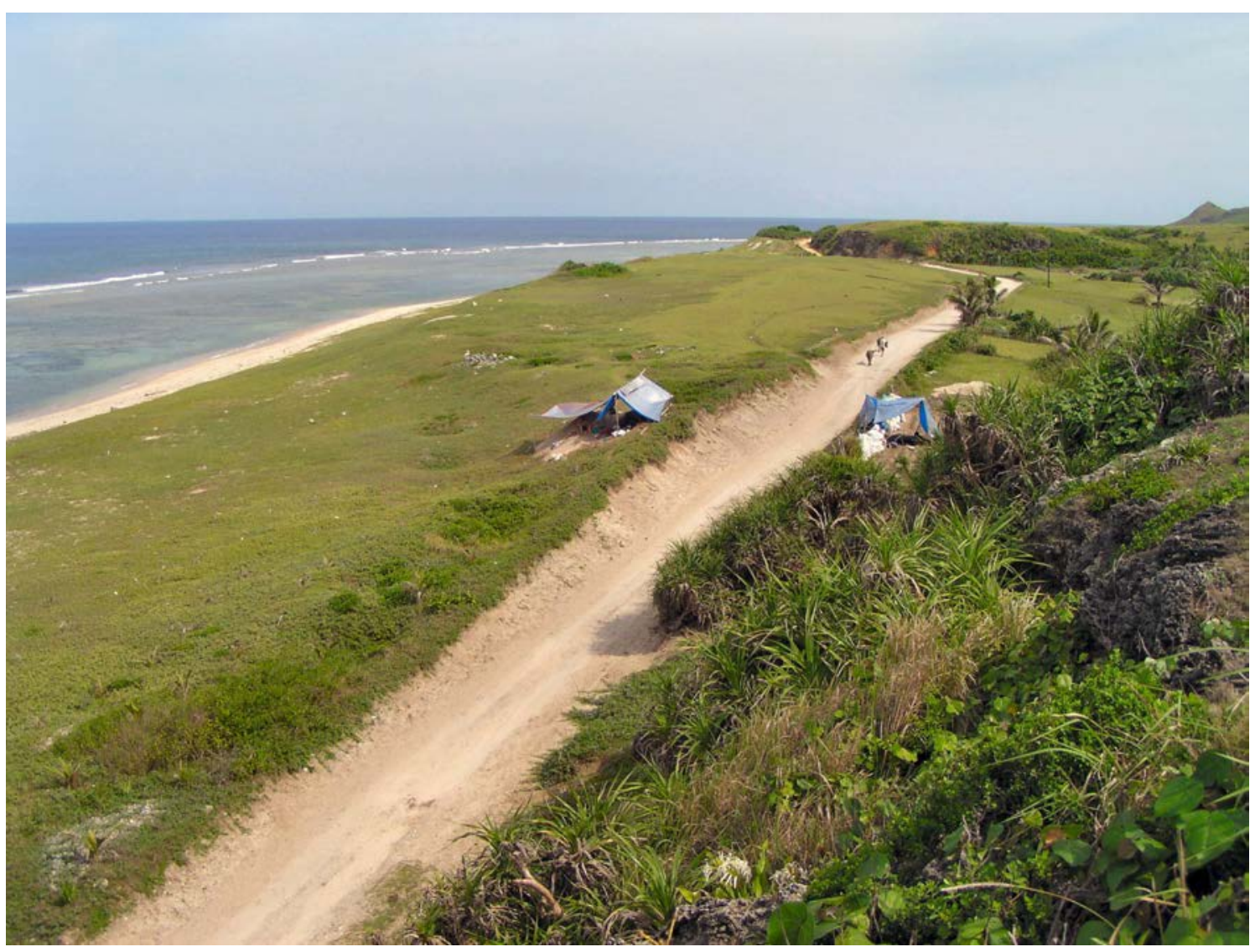

Figure 4.9. Savidug Dune Site from the top of the $8 \mathrm{~m}$ bluff, looking southwards. To the left is excavation E1-G1/9-11, to the right $\mathrm{QR} / 7-9$, with spoil from K-N/27-29 just behind.

Source: Peter Bellwood. 




Figure 4.10. Looking north from the Savidug Dune Site in 2006. The 2006 test pit is to the left, the bluff with the water tanks behind, the road cutting that first yielded the burial jars straight ahead, and Savidug village lies at the rear amongst the young coconut palms, across Padudugan stream bed.

Source: Peter Bellwood.

Bellwood's field notes for 2003, together with a short manuscript report by Pamela Faylona, indicate that two of the jar burials then exposed were cleaned and examined. One contained the bones of a child, of which a sample of tooth enamel was subsequently dated to 1728-1569 BP (Table 5.1, sample ANU 33938). The other, a large red-slipped jar with a girth of $62 \mathrm{~cm}$, had its broken-off rim placed upside down inside, and contained only a few adult phalanges. Both jars were partly on their sides rather than vertical. No artefacts were discovered and all the jars appeared to have been disturbed, perhaps not surprisingly owing to their easy visibility from the road. The jars found in 2003 were not surveyed accurately and can no longer be related exactly to the positions of those excavated in 2006 and 2007 (Fig. 4.12).

\section{Excavations in the Savidug Dune Site}

In April 2006, we decided to undertake a test excavation in the site, and laid out a 2x1 trench in a field on top of the dune, about $8 \mathrm{~m}$ west of the road. This is labelled as excavation no. 5 in Fig. 4.11, and located in more detail in Fig. 4.12. It produced a sequence of five layers, beginning with 40 to $70 \mathrm{~cm}$ of loose ploughed soil derived nowadays from peanut cultivation (layer 1) over a dark grey sandy loam (layer 2), about 20-30 cm thick, with late prehistoric material culture similar to that from Pamayan (above). Beneath layer 2 was sterile dune sand (layer 3), then a second humic sandy cultural deposit (layer 4) with its top at about 1.4 metres below the ground surface. Layer 4 , about $40 \mathrm{~cm}$ thick, was quite rich in material culture, with red-slipped pottery and a date of $2828 \pm 37$ uncal. BP (Wk 19711) from its base at $180 \mathrm{~cm}$. This pottery included a sherd of circle stamped pottery in Sunget (Batan) style, also dated at Sunget to $c .1000$ BC (chapter 3). A slightly more complex version of this stratigraphic sequence, recovered from Q/R7-9 in 2007, can be seen in Fig. 4.13. 




Figure 4.11. Savidug Dune Site: area plan with excavations in 2006 and 2007.

Source: Map preparation by ANU College of Asia and the Pacific, CartoGIS. 


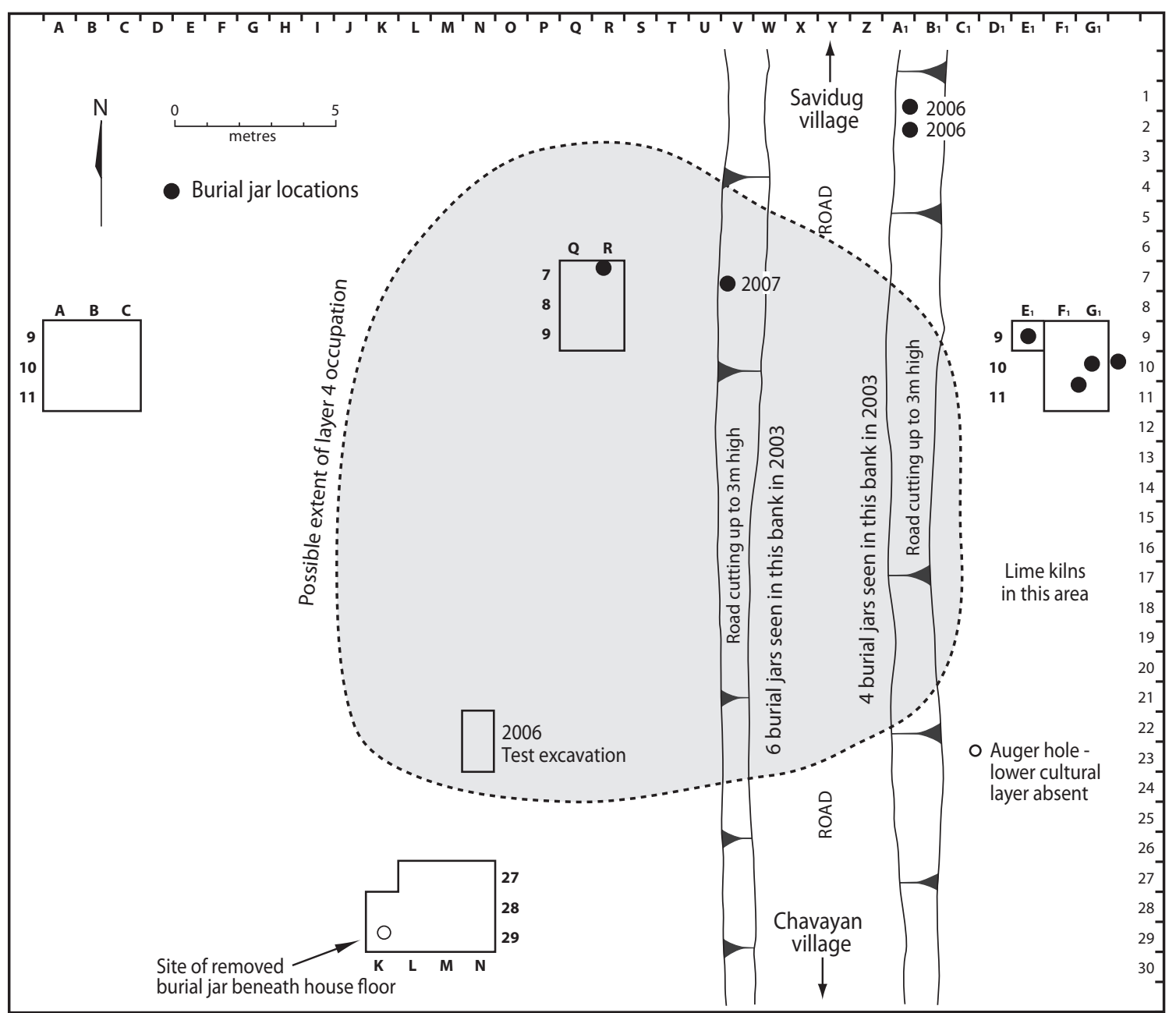

Figure 4.12. Savidug Dune Site: detailed locations of excavated areas and burial jars (circles), 2006-2007.

Source: Map preparation by ANU College of Asia and the Pacific, CartoGIS.

Beneath layer 4 lay more sterile dune sand, which we decided to auger rather than excavate since the trench walls, partly in loose dune sand, were already showing signs of collapse. Augering reached another humic sand (old topsoil) at 3.1 metres below ground level and $40 \mathrm{~cm}$ thick, but with no sign of any cultural presence. This overlay another culturally-sterile dune sand that continued to 4.3 metres below the surface, when augering had to stop owing to lack of rods. It is apparent that the site was not occupied beneath layer 4, at least not in this area.

Two more jar burials were observed in the seaward side of the road cutting in 2006, and one was excavated (Fig. 4.14). It consisted of a lower jar $58 \mathrm{~cm}$ in girth and $60 \mathrm{~cm}$ in surviving height, with a slightly pointed base, red slipped, and rimless. As we learnt in 2007, these burial jars had mostly had their rims removed to take primary and presumably flexed burials, like contemporary (Iron Age) burial jars in regions as far apart as Sarawak and southern Vietnam (observations by Peter Bellwood). The lid of this vessel was the lower part of another large rimless globular vessel, simply placed upside down over the mouth of the lower vessel. A virtually identical combination was also excavated in Q/R7-9 in 2007 (Fig. 4.15). As can be seen from Fig. 4.12, if we add the six jars investigated in 2007, the total from the gridded area of the site, incorporating a stretch of roadway and adjacent land about $30 \mathrm{~m}$ long by $29 \mathrm{~m}$ wide, is now 14 . 


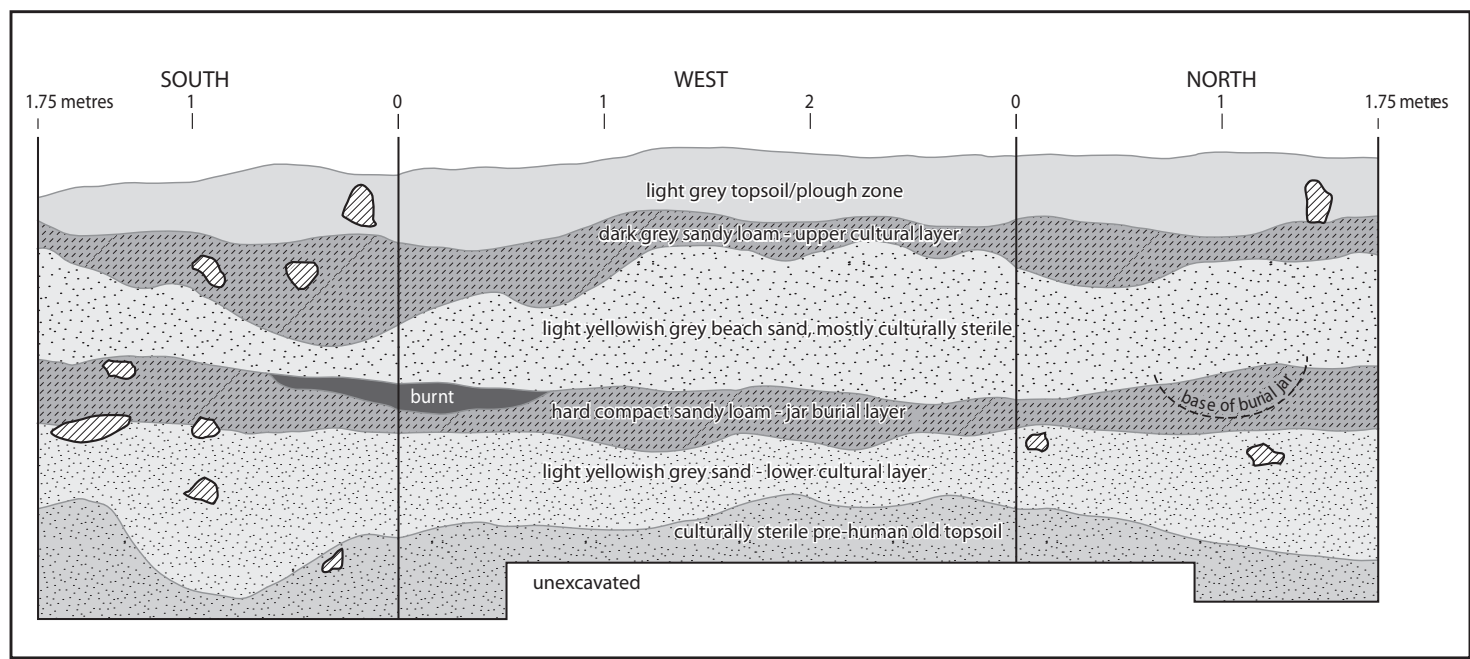

Figure 4.13. South, west and north sections of Savidug Dune Site trench QR/7-9, excavated in 2007.

Source: Map preparation by ANU College of Asia and the Pacific, CartoGIS.

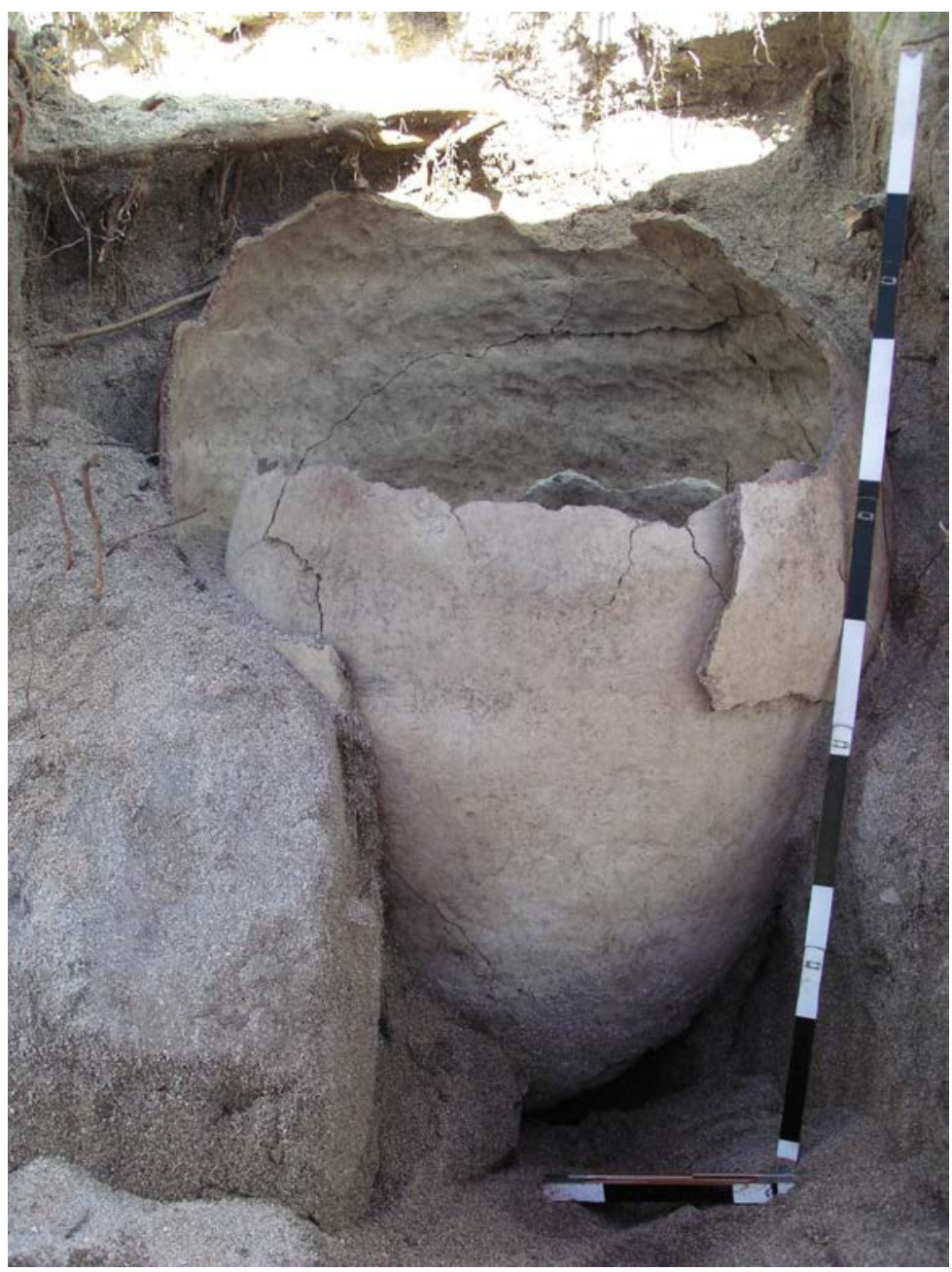

Figure 4.14. Savidug Dune Site: a burial jar excavated in 2006, with a rimless lower jar, and a similar rimless jar placed upside down over the top as a lid. This contained human bone, but no artefacts.

Source: Peter Bellwood. 


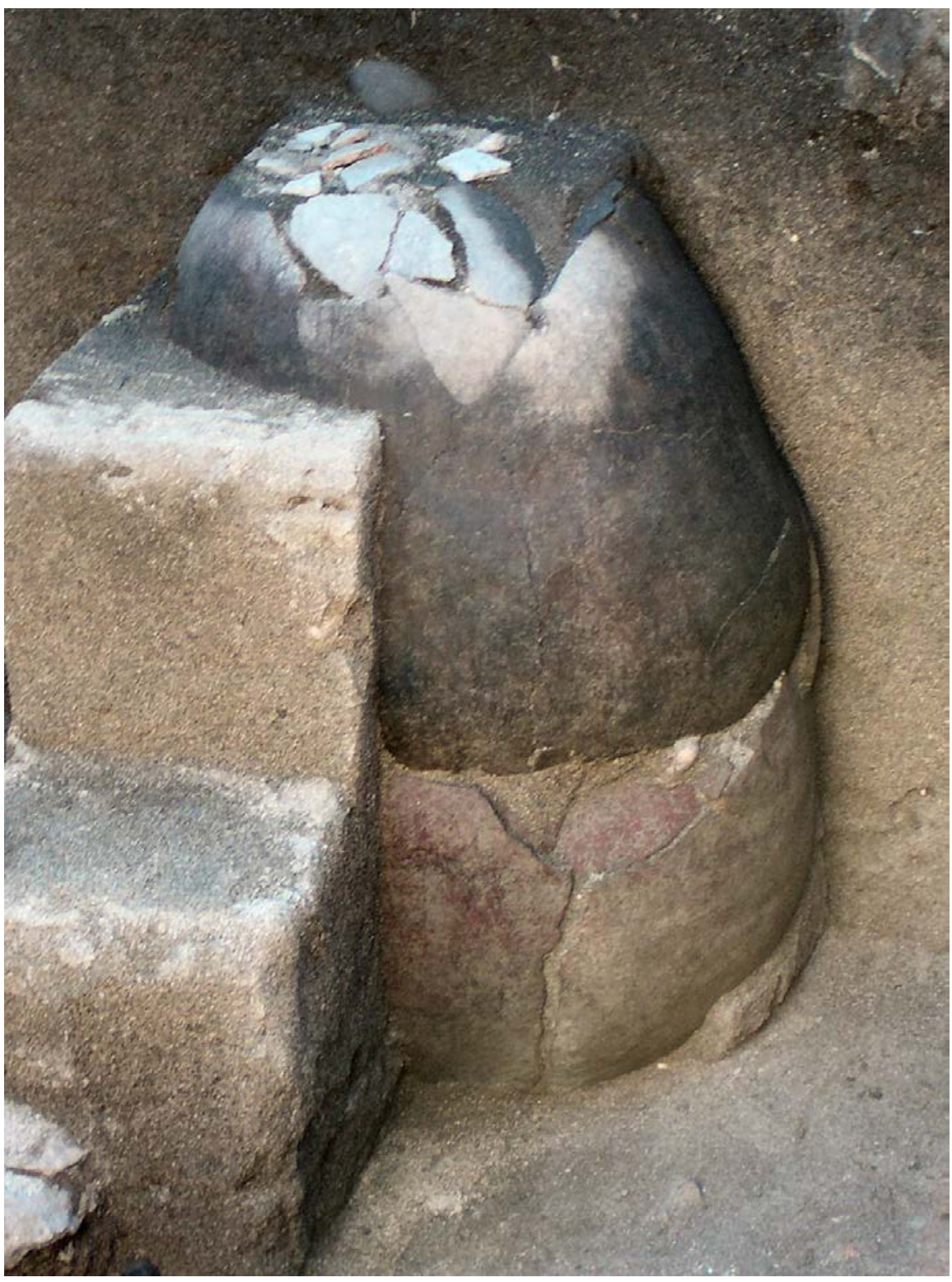

Figure 4.15. Savidug Dune Site: the lidded burial jar excavated in QR/7-9.

Source: Peter Bellwood.

Observation of the road section in 2006 suggested that these burial jars perhaps had their bases embedded in the top of the lower cultural layer (layer 4), but this was not really very clear and the mystery led us to return in 2007 to investigate the matter properly. One very remarkable surface find in 2006 was a baked clay casting mould found in three matching pieces in the road, broken by passing traffic, and hence an extremely lucky find (Fig. 8.11 F). We believe, but cannot be certain, that it came from layer 4, and if so it could be about 2000 years old. A small piece of copper was also found nearby in the road, subsequently analysed by Oli Pryce (pers. comm.) and shown to be actual metal rather than slag. The mould, $8.2 \mathrm{~cm}$ long, appears to have been one of a bivalve pair for casting a socketed tool with a slightly splayed blade, probably an adze or chisel. A similar baked clay mould was found by the 1982 Japanese team at Tayid on Batan Island (Koomoto 1983: plate 32; and see Fig. 8.11 G below), probably pre-dating 1500 BP since this site is buried under the Iraya ash layer. However, as noted in the report on Tayid in chapter 3 , the Japanese team did not indicate where the mould was found - it could have been a surface find. 
Nevertheless, both of these moulds are important discoveries since they indicate casting of cupreous metal in Batanes, presumably using imported scrap or ingots, at around or possibly before 2000 years ago. As with the nephrite found in the Batanes Islands (chapter 9, and see Hung et al. 2007), one wonders if itinerant metalworkers were involved, since the Batanes Islands themselves have no native copper resources, although other regions of the Philippines do.

\section{The 2007 excavation in the Savidug Dune Site}

In 2007, we decided to undertake fairly extensive excavation at Savidug Dune Site in order to find out more about lower cultural layer 4 and its relationship with the jar burials. An area of 30 by 30 metres was chosen for a surface grid of $1 \mathrm{~m}$ squares, running across the road where the burial jars had been found previously and over the sand dune on either side of the road. The four trenches indicated in Figs 4.11 (numbers 1,2,3 and 4) and 4.12 were excavated, and the basic results in terms of $\mathrm{C} 14$ dates and artefact distributions are given later in this monograph in Tables 6.6 and 8.1. These tables make clear the distinction between cultural layers 2 (upper) and 4 (lower), and the sterile sand layer 3 that lies in-between.

\section{Excavation trench $K-N / 27-29$}

We began with a 3 by $3 \mathrm{~m}$ trench of 9 conjoined squares, LMN/27-29, extended later into K28 and 29 to expose an aligned $1.5 \mathrm{~m}$ long segment of a boulder house foundation in the upper cultural layer (layer 2). This probably held in place the base of a bamboo or cogon grass house wall in late prehistory (Fig. 4.16). A circular pit below this, about the size of a burial jar, went down into the upper part of layer 4 , and we presume this represents the removal of a former burial jar protruding above the surface of layer 3, still visible at the time the house wall was constructed (see Fig. 4.12 for location). This trench produced a much higher density of upper cultural layer sherds than did the nearby 2006 test trench, perhaps because of the presence of the house. The layer sequence here was identical to that observed in 2006, but here the lower cultural layer, layer 4, contained only limited material. This area was clearly on the southern edge of the early occupation.

\section{Excavation trench $A-C / 9-11$}

The upper cultural layer in this 3 by $3 \mathrm{~m}$ excavation trench was very dense in artefacts and midden material, especially at 50-60 cm. It lies at the base of a slope that descends from the rocky hillock that today supports the water tanks (Figs 4.10, 4.11). A great deal of the clay and silt matrix of layer 2 in this trench, as opposed to the sand matrix that dominates in all the other trenches, was clearly washed down in the past from this hill. Indeed, this trench also contained occasional cultural materials that appeared to be of lower cultural period origin, even though this layer was not represented in this location. Occupation on the hill behind had presumably released soil for downwash on to the dune below, including in one case a complete pot that had been washed with rocks and clay into square $\mathrm{C} 10$, presumably during a torrential downpour. This pot was of upper cultural layer affinity, but it is possible that the hill top was occupied during the lower cultural phase too. If the A-C/9-11 area at the base of the hill was actually occupied, and it has to be stated clearly that this is not proven in the absence of any stone house walls (cf. K-N/27-29 above), then the date of this occupation is generally late, presumably between 1000 and $600 \mathrm{BP}$ according to the monochrome ceramics recovered throughout (no blue and white - Fig. 4.17). As stated, no coherent sign of the lower cultural layer 4 was observed in this trench, suggesting that occupation and jar burial at this time did not occur at the base of the hill. However, as far as our excavations were concerned this was by far the area of densest artefact accumulation of the upper cultural phase. 




Figure 4.16. Savidug Dune Site KL/28-29, boulder house foundation in the upper cultural layer (layer 2), probably once holding in place an organic wall of bamboo or cogon grass. Date perhaps c.500 BP.

Source: Peter Bellwood.

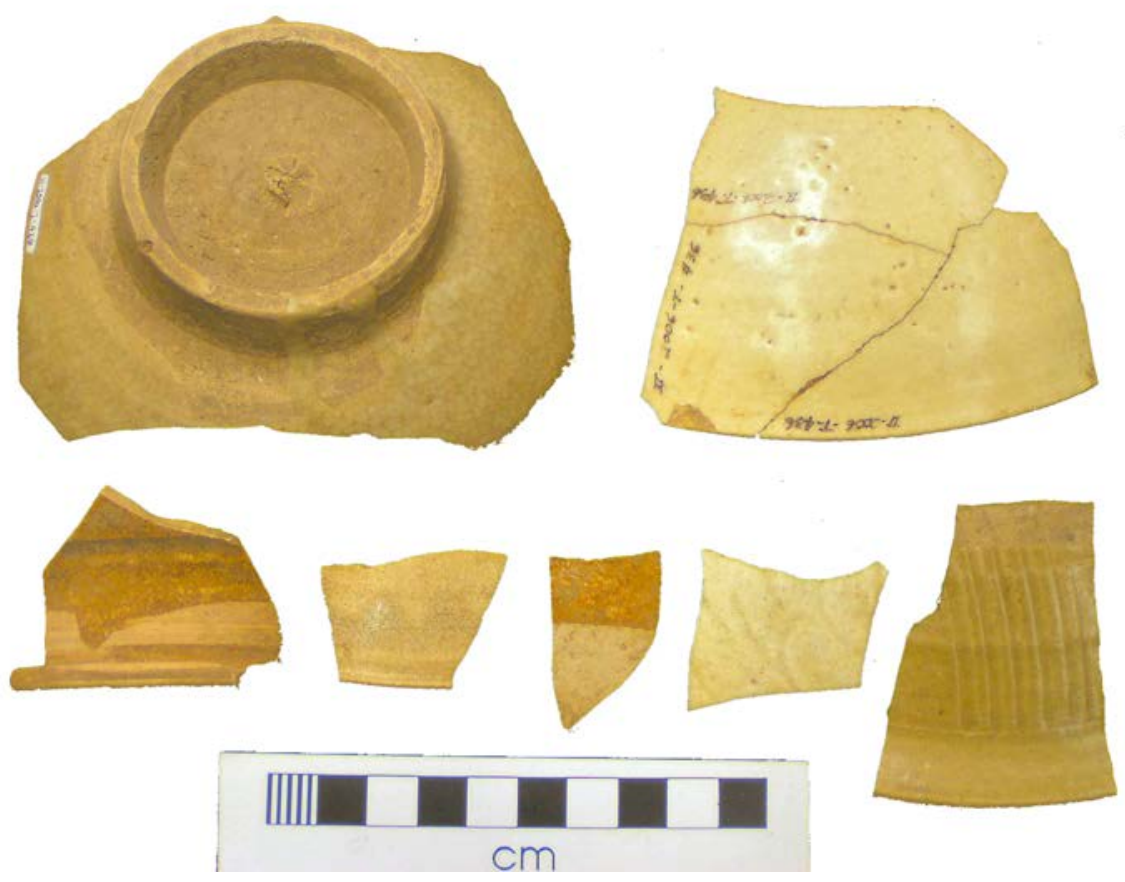

Figure 4.17. Savidug Dune Site: monochrome Asian export ceramics from the upper cultural layer. Presumably, the dates for these focus on the Song and Yuan Dynasties.

Source: Peter Bellwood. 


\section{Excavation trench E1-G1/9-11}

This trench was excavated on the seaward side of the road under the direction of Marc Oxenham, with the main intention being to understand the placement of the burial jars in the site. Luckily, four were discovered in this trench, with that in $\mathrm{E}_{1}$ and that in the $\mathrm{H}_{1}$ baulk being badly broken. The other two in the main part of the trench were well preserved and still standing upright, albeit with only poor bone preservation. The upper cultural layer in this trench had been badly disturbed by the digging of recent lime pits, and sherds were fairly few. The lower cultural layer, as an occupation rather than as a locus of jar burials, was virtually absent, although layer 4 was there as an old topsoil.

The complete burial jar shown in Figs 4.18 and 4.19, and reconstructed in Fig. 4.20, together with the other broken jars found in this trench, had its base embedded at the level of upper layer 4 and its body encased entirely in the sterile sand of layer 3 . When the upper cultural layer 2 was laid down these jars would therefore have been already buried under sand, although some elsewhere might have been visible, or within easy reach of discovery. The burial jar illustrated is the most interesting one discovered so far. It had a badly broken small lid consisting of a redslipped bowl placed upside down, partly removed in the photo to reveal the rim of the main jar below. The main jar has been drilled and chiselled from the inside to remove the upper part, like breaking off the top of a boiled egg - the line of this removal is clearly visible near the top of the jar in Fig. 4.19 and is marked in Fig. 4.20. The poorly preserved remains of an adult primary burial were then placed inside and the upper part of the jar was placed back on, perhaps with clay "glue" (we are not sure about this), and the lid put in place. This jar, and all the others, was then placed upright on the ground surface, perhaps in a small stabilising hollow, in the upper $30 \mathrm{~cm}$ or so of layer 4. The jar burial tradition at Savidug thus dates to the later part of layer 4, hence second half of the first millennium $\mathrm{BC}$ and early first millennium $\mathrm{AD}$, according to the $\mathrm{C} 14$ dates to be discussed in chapter 5 .

It should be stated that we have never found a single artefact in a burial jar at Savidug, except for a few sherds broken from rims and lids. Unlike jar burial sites further south in the Philippines, Indonesia, and central and southern Vietnam, where large numbers of small accessory vessels, ornaments, and so forth occur inside and around the burial jars (e.g. Tabon Caves on Palawan), the Batanes people appear to have used them only for burial, pure and simple. This was perhaps because the jars were placed deliberately above the ground surface in an open and exposed site, rather than being buried or placed in a hidden cave, thus visible and of course amenable to being ransacked. The nephrite lingling-o to be described later, found in trench QR/7-9, was apparently buried deliberately in a hole adjacent to the base of a burial jar.

Another interesting question concerns the origin of the sterile dune sand layer 3 that buries the jars and covers layer 4 . Was this created by normal dune movement owing to wind? Or might there have been a tsunami from the cataclysmic eruption of Mt Iraya on Batan at c.1500 BP? If the latter, one wonders how the jars survived at all, and we have never seen any trace on Sabtang of the Iraya volcanic ash layer that mantles Batan Island. Slow dune migration seems the most likely possibility for the burial of layer 4 at Savidug Dune Site at present.

\section{Excavation trench QR/9-11}

This was by far the most prolific trench for the lower cultural layer 4, the upper cultural layer 2 being rather ephemeral here. The lower layer in the $\mathrm{QR}$ trench was more complex than elsewhere, with cultural material not only in the old topsoil layer 4, but also quite densely in the sand dune layer 5 below, that elsewhere was sterile (Fig. 4.13). As can be seen from Tables 6.6 and 8.1, layers 4 and the top of 5 in QR were $130 \mathrm{~cm}$ thick in combination, by far the thickest in the site. 


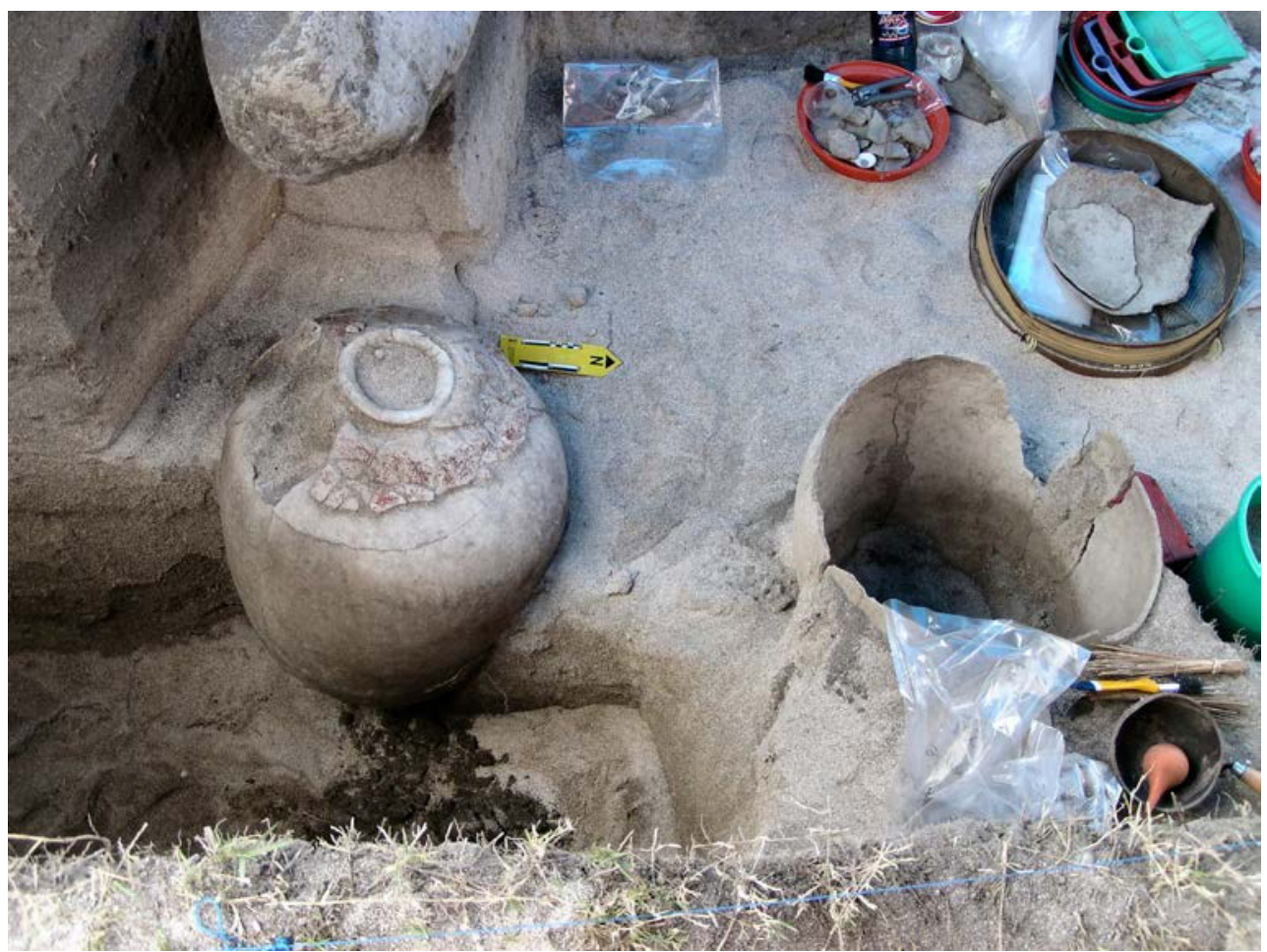

Figure 4.18. Savidug Dune Site: two burial jars exposed in trench E1-G1/9-11, the right hand one already emptied.

Source: Peter Bellwood.

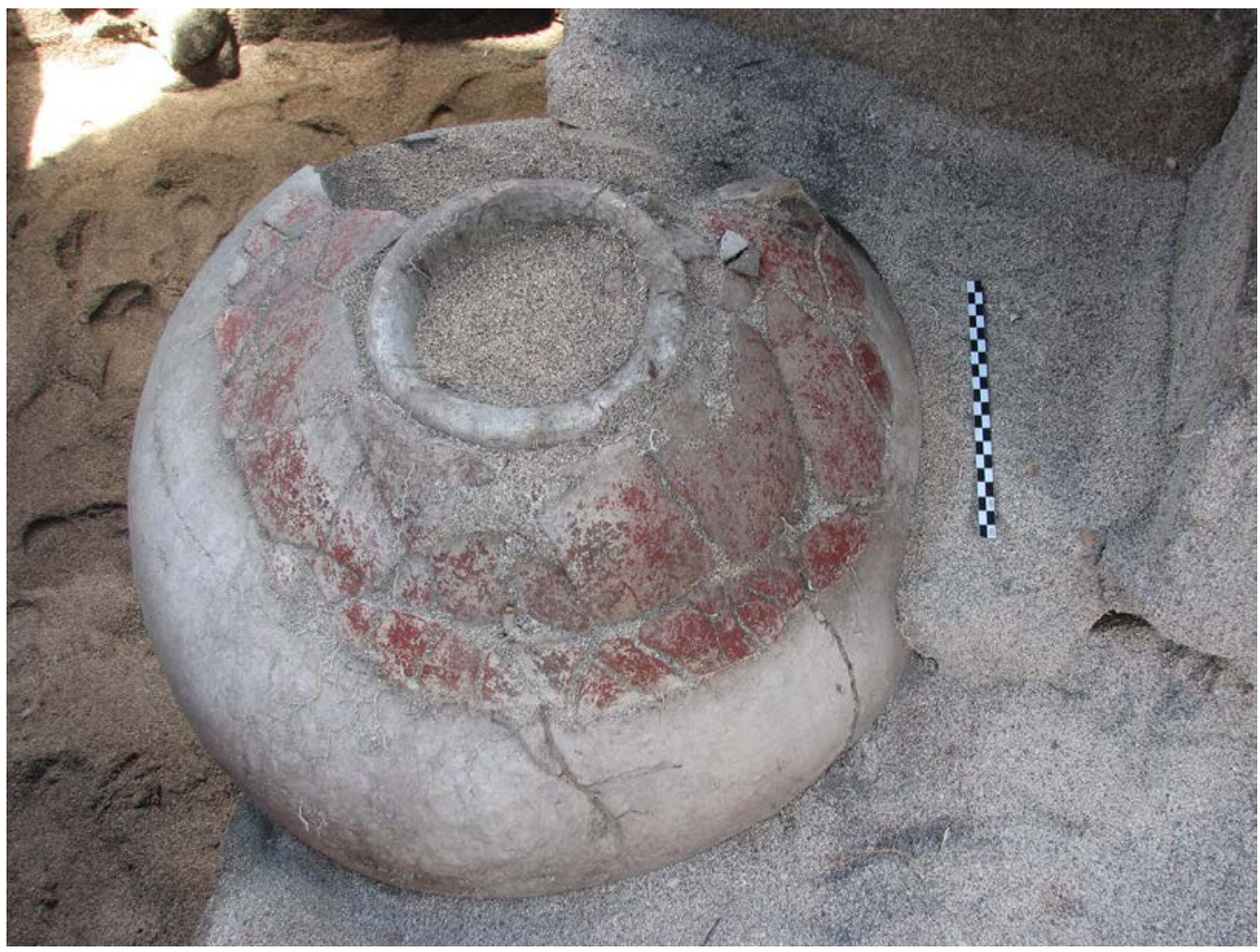

Figure 4.19. Savidug Dune Site: complete burial jar in E1-G1/9-11 with the lower part of its red-slipped lid still in place. The upper part of the vessel was removed in antiquity and put back, in order to contain a primary burial.

Source: Peter Bellwood. 
top of jar deliberately removed

by chiselling around

the circumference

from within

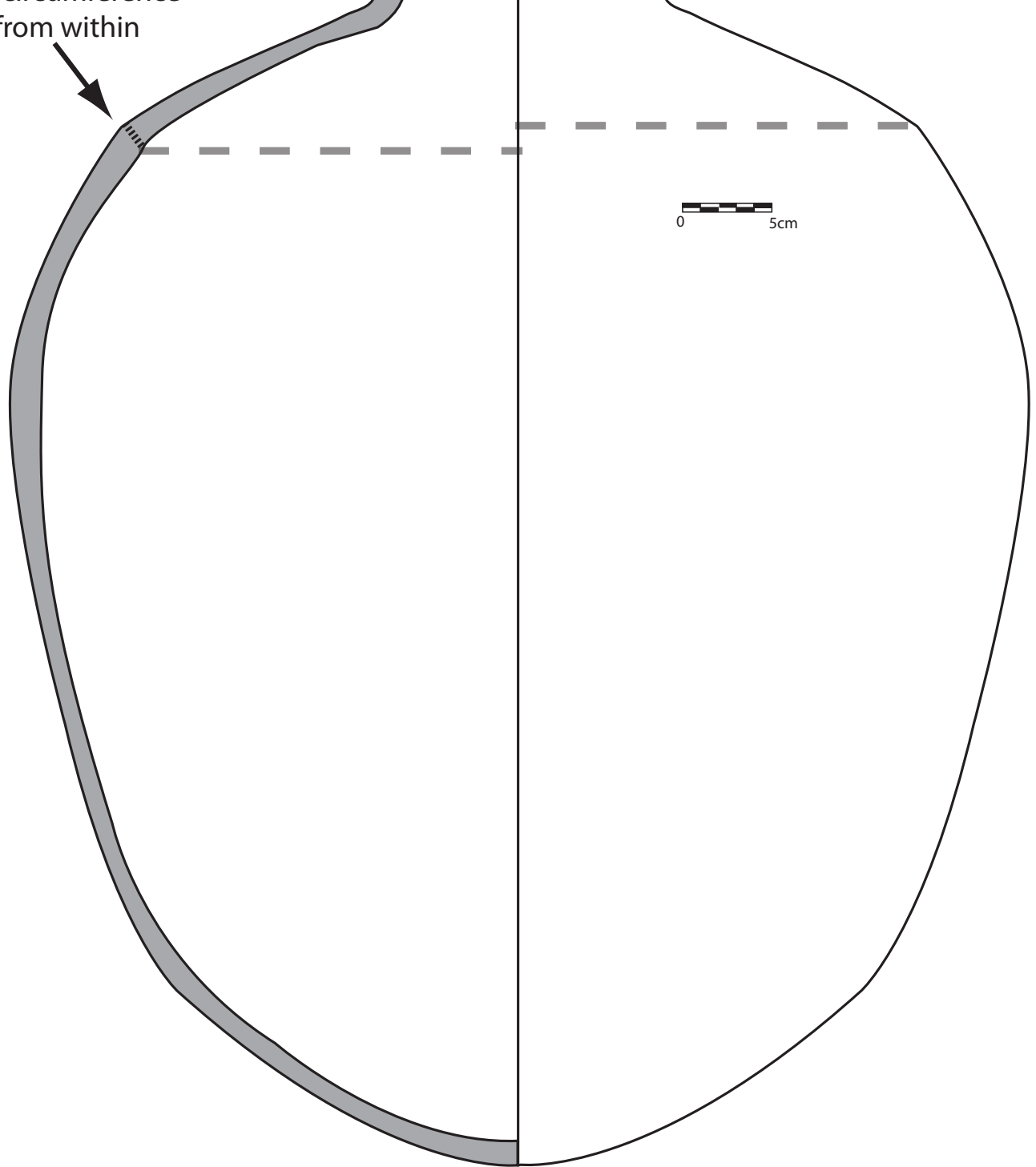

Figure 4.20. Savidug Dune Site: the jar in Fig. 4.19, showing the location of the deliberate break to lift the upper part of the jar to insert the body. The lid is not shown - it was too badly damaged to reconstruct, but was a red-slipped and presumably round-based open bowl.

Source: Peter Bellwood.

Pottery density is greatest at about $120 \mathrm{~cm}$ below the surface, which is where the bases of most of the burial jars were placed, suggesting that activity in the actual jar burial phase was rather intensive. However, pottery extends far below the jar burials, down to the two C14 dates (here and in the 2006 test trench) of $c .1000 \mathrm{BC}$. So jar burial cannot be stated to have been an activity in the early years of occupation, and it perhaps commenced after $500 \mathrm{BC}$.

One complete and undisturbed burial jar was excavated at the north end of QR/7-9 (alas, like all the others, with no surviving artefacts). This is similar to the one described above from 2006 (Fig. 4.14), having a lower red slipped jar with its top cut off, and a lid made from the lower part of a similar vessel (Fig. 4.15). The nephrite lingling-o shown in Fig. 9.2 was buried just to 
one side of the base of this jar, with charcoal in the immediate vicinity dated by Wk 21809 to about 500-400 BC. This is one of the best dates for a nephrite ornament of this type in Island Southeast Asia, as discussed further in chapter 9. It can also be seen from Table 8.1 that a number of archaeologically informative artefact categories extend through layer 4, and also into layer 5 in QR7-9. These are discussed later.

\section{0 years of occupation at Savidug}

Tables 6.6 and 8.1 indicate that Savidug Dune Site has two stratigraphic and cultural phases of usage: an upper cultural layer (layer 2) dated c. 1000 to $600 \mathrm{BP}$, with imported ceramics and iron, and a lower cultural layer dated c.3200 to 2000/1500 BP (layers 4/5). The lower cultural layer can be divided into an earlier and a later phase. The earlier is associated with rare examples of circle-stamped pottery, dated 3200 to $2700 \mathrm{BP}$ in the site and from some fairly precise parallels at Sunget and Anaro. The later phase, dated c.2700 to 2000/1500 BP, is associated with jar burial, Taiwan nephrite and possibly copper working.

The quantity of circle stamped pottery at Savidug is rather small compared to Sunget and Anaro, raising the possibility that it was imported from another Batanes location. Interestingly, the lattice pattern of stamped circles that is associated with nephrite working at Anaro is absent at Savidug, where the nephrite is mainly associated with plain pottery (see chapter 6).

Table 4.1 contains data on the ratios of smashed cowries to other shell species for upper cultural layer 2 (c.1000 to $600 \mathrm{BP}$ ) in the A-C and K-N squares at Savidug Dune Site. This table has been constructed from data counted at the time of excavation, and is therefore complementary to the post-excavation analytical data presented in chapter 12 . In the A-C squares, there is a fairly consistent rise over time in the proportion of smashed cowries to other shell species in cultural layer 2 (except for the $100-110 \mathrm{~cm}$ depth, which has a small sample size). A similar but less regular pattern occurs in K-N. The point to note here is that this focus on small cowrie shells, broken open energetically to remove the contents, is highly emphasised in the upper cultural layer at Savidug Dune Site, as at Pamayan. It is also reflected in the intensive fragmentation of animal bones at Pamayan, as discussed in chapter 10. This could relate to considerable pressure on resources during that relatively late period in Batanes prehistory, corresponding with the stressful and feud-ridden lifestyle recorded by visitors such as Jirobei in 1669 and Dampier in 1687 (see chapter 1). This issue is also discussed from a slightly different and more ecological perspective in chapter 12.

Table 4.1. Weights and relative frequencies of smashed cowrie shells in the upper cultural layer at Savidug Dune Site.

\begin{tabular}{|c|c|c|c|c|c|c|}
\hline & \multicolumn{3}{|c|}{ 2007 A-C/9-11 (3 by 3 m) } & \multicolumn{3}{c|}{ 2007 K-N/27-29 (3 by 3 m) } \\
\hline Depth cm & Smashed cowrie gm (approx.) & Non-cowrie gm & $\begin{array}{l}\text { Ratio cowrie } \\
\text { to non-cowrie }\end{array}$ & $\begin{array}{l}\text { Smashed cowrie } \\
\text { gm (approx.) }\end{array}$ & $\begin{array}{l}\text { Non- } \\
\text { cowrie gm }\end{array}$ & $\begin{array}{l}\text { Ratio cowrie to non- } \\
\text { cowrie }\end{array}$ \\
\hline $0-20$ & Plough zone & & & 268 & 305 & 0.88 \\
\hline $20-40$ & 2870 & 1420 & 2.02 & 1137 & 925 & 1.23 \\
\hline $40-50$ & 5447 & 3848 & 1.42 & 2220 & 1084 & 2.05 \\
\hline $50-60$ & 12,596 & 8185 & 1.54 & 2919 & 1167 & 2.50 \\
\hline $60-70$ & 2943 & 3882 & 0.76 & 688 & 1030 & 0.67 \\
\hline $70-80$ & 1075 & 1390 & 0.77 & 1305 & 1830 & 0.71 \\
\hline $80-90$ & 1000 & 1813 & 0.55 & - & - & - \\
\hline $90-100$ & 300 & 440 & 0.68 & - & - & - \\
\hline $100-110$ & 1200 & 210 & 5.7 & - & - & \\
\hline
\end{tabular}

